\title{
POLITICS OF THE PTOLEMAIC DYNASTY
}

\author{
Monica Omoye Aneni* \\ http://dx.doi.org/10.4314/og.v12i 1.7
}

\begin{abstract}
Hellenistic studies and Egyptology have concentrated on the spread and influence of Hellenism, on the one hand, and the value of ancient Egypt's monument and artifacts, on the other hand. This study focuses on the politics that directed and helped sustain the successors of Alexander the Great on the throne of Egypt. Ptolemy 1 Soter, the instigator of the Ptolemaic dynasty, fought vehemently, gallantly and decisively to consolidate his authority and control over Egypt and her consequent spread. However, his successors played several politics; majorly that of assassination, for the enviable position of Pharaoh, unfortunately, to the detriment of the state. This study contends that besides the earliest Ptolemies, the other successors, having ignored the legacy of Ptolemy 1 Soter and the expansion of Egypt's frontiers, fostered and nurtured this politics of assassination among others. It concludes with the argument that the contenders encouraged political retrogression to the nadir and therefore were not fit for the throne, for this politics of assassination among others reduced Egypt and hindered her from attaining the status of a much more formidable world power that would have been reckoned with during that period. The study is historical in nature but adopts the expository method. Studies that may interpret Egypt's strong diplomatic relations with other ancient nations are recommended.
\end{abstract}

Keywords: Politics, Egypt, Ptolemaic dynasty, successors, assassination

\section{Introduction}

Several ancient authors present expository narratives about different political, economic, social and religious activities of the 
various eras that characterize ancient times. Some of these authors ${ }^{1}$ did adumbrate narratives that link us to ancient Egypt, the wars and conquest of Alexander the Great, Hellenistic Egypt, the Seleucid dynasty, the Near East and many more. Modern authors while relying on ancient sources attempt to explain events that occurred in Hellenistic Egypt, presenting vivid pictorials of Hellenistic art, architecture, and religious temples. They also examine personalities in the trajectory of Hellenistic study with regard to Ptolemaic Egypt. Hobl $(2001)^{2}$ discusses the rise and fall of Ptolemaic leadership in Egypt and also attributes the success of the Ptolemies partly to adopting some elements of former Pharaohs of Egyptian descent; funding of cults and temples. Manning (2012) ${ }^{3}$ mentions the impact of the Ptolemaic rulers on Egypt due to the reforms they adopted. These policies aided in reconstructing Egypt into a hybrid culture that was both Egyptian and Greek shaping Egyptian society as well as the Ptolemies themselves. Bingen et al (2007) ${ }^{4}$ examines Hellenistic Egypt and her successes until her annexation by the Roman Empire under Octavian. Bingen demonstrates that Hellenistic Egypt was a paragon of beauty, sophisticated, rich and a fertile country. Chauveau (2000) ${ }^{5}$ paints a picture of Egypt under the leadership of the last Pharaoh of Egypt, Cleopatra VII. Chauveau departs from ancient sources and relies mostly on

\footnotetext{
${ }^{1}$ Arrian, Annabasis of Alexander, translated by Brunt, P.A., 1976, Harvard University Press; Polybius, 2009, The Complete Histories, of Polybius, translated by Paton, W.R, Digireads.com; Plutarch, 1977, The Parallel Lives, Modern Library.

${ }^{2}$ Hobl, Gunther, 2001, A History of the Ptolemaic Empire, Psychology Press

${ }^{3}$ Manning J.G., 2012, The Last Pharaohs: Egypt Under the Ptolemies, 30530 BC.Princeton University Press.

${ }^{4}$ Bingen, Jean, Midgley, Stuart, \&Bagnall, Roger, 2007, Hellenistic Egypt, Society, Economy, Culture (Hellenistic Culture and Society). University of California Press:

${ }^{5}$ Chauveau, Michel, 2000, Egypt in the Age of Cleopatra: History and Society Under the Ptolemies, Cornell University Press.
} 
evidence from firsthand accounts, numismatic, Greek, demotic and hieroglyphic inscriptions in an attempt to describe Egypt and her grandeur under Cleopatra VII. These various authors; ancient and modern, have rigorously examined Egypt of the eras pre and during the Hellenistic eras. This study deviates from the works of other authors as it focuses on the politics and power tussle among heirs to Egypt's throne in the Hellenistic era while presenting informative and historic account of the Ptolemaic dynasty.

\section{Egypt}

The civilization of ancient Egypt coalesced in about 3,150 BC. The political unification of Upper and Lower Egypt occurred under the first pharaoh. Egypt thrived during this period. ${ }^{6}$ Egypt's progress was punctuated with unstable eras called intermediate periods and Egypt experienced progress in the stable periods such as the Old Kingdom, the Middle Kingdom and the New Kingdom. In the New Kingdom, Egypt reached the Zenith of her power such that she rivaled other kingdoms such as the Assyrian Empire, the Hittite Empire and the Mitanni Empire.

The capacity of the Pharaohs to manage the resources of Egypt which was the Nile placed Egypt on that pedestal of prosperity that attracted the interest of other nations. However, Egypt experienced decline even as she was subdued and ruled by foreign powers such as the Cannanite/Hyksos, Libyans, Nubians, Babylonians, Assyrians, Achaemenid Persians and the Macedonians. Egypt also came under the domination of Alexander the Great, and in the aftermath of his death, came under the suzerainty of one of Alexander's General, Ptolemy 1 Soter. He became the author of the Ptolemaic dynasty in Egypt. Egypt under this dynasty thrived until she began to experience decline under succeeding dynastic rulers

\footnotetext{
${ }^{6}$ Dodson, Aidan; Hilton, Dyan, 2004, The Complete Royal Families of Ancient Egypt. P. 46, London, England: Thames \& Hudson
} 
due to lack of effective management. Having been subjugated by hegemonic Rome, Egypt became a Roman province in 31BC.

\section{Ptolemies of Egypt}

After the death of Alexander the Great in 323 BC, Perdiccas, one of the Generals of Alexander the Great became the ruler of Alexander's empire. He ruled as king in the stead of both Philip III and Alexander IV of Macedon. Perdiccas then appointed Ptolemy (another General of Alexander the Great) to become the satrap of Egypt and ruled in the name of Philip III and Alexander IV. As Egypt fell to Ptolemy, he took the title soter meaning 'savior.' Ptolemy 1 Soter was a Macedonian Greek and members of the dynasty he established were of Greek extraction, Prudence $(2006)^{8}$, Pomeroy (1990) ${ }^{9}$ and Bard (1990). ${ }^{10}$ Ptolemy 1 Soter became the author of the Ptolemaic dynasty which endured for over 300 years. As the Ptolemies also became Pharaohs, they married their siblings in the traditions of the Egyptians. The Ptolemaic kings took the name Ptolemy while the princesses and queens took any of the names Cleopatra, Arsinoe or Berenice. In the characteristics of Hellenistic culture and civilization, the Ptolemies tolerated and adopted some elements of the religion and customs of the Egyptians and went ahead to construct magnificent temples for Egyptian gods.

\section{Ptolemy 1 Soter}

In $321 \mathrm{BC}$, Perdiccas attempted to invade Egypt but failed even as Ptolemy 1 Soter fought vehemently and decisively to consolidate his control over Egypt. As Perdiccas fell at the hands of

${ }^{7}$ Clayton, Peter A., 1994,. Chronicle of the Pharaohs p 217, . London, England: Thames and Hudson

${ }^{8}$ Jones, Prudence J. (2006). Cleopatra: A Sourcebook. University of Oklahoma Press.p. 14.

${ }^{9}$ Pomeroy, Sarah B., 1990, Women in Hellenistic Egypt. Wayne State University Press. p. 16

${ }^{10}$ Bard, Kathryn A., ed., 1999, Encyclopedia of the Archaeology of Ancient Egypt. Routledge. p. 687 
his own men, ${ }^{11}$ and Alexander IV was assassinated, Ptolemy remained the sole satrap of Egypt. Having secured his power base, Ptolemy planned to also secure his hold in far-flung areas such as Cyrenaica, Cyprus, Syria and Judea. He occupied Syria in 318 and in 315 joined a league against Antigonus Monopthalmus the one eyed stratagos of Asia, when Antigonus desired to invade his territories. He took Cyprus from Antigonus in 313 and also quelled a revolt in Cyrene. As the war raged on, Ptolemy together with Seleucus, the satrap of Babylonia invaded Syria and defeated Demetrius Poliorcetes (besieger of cities), the son of Anitigonus Monolpthalmus in the battle of Gaza. However, Syria was reclaimed by Demetrius. In 311, a truce was called and a peace treaty signed between thewarriors. Ptolemy I Soter displayed power politics in his role as hegemon over Egypt. He believed in a greater Egypt and his capacity to control, prosper, protect the city against invaders and expand her frontiers. Resisting Perdicas, joining a coalition against Antigonus and taking control of Egypt's outlying areas are demonstrations of his display of power politics.

In 309, He wrested the coastal towns of Lycia and Caria from Antigonus. He also took possession of Corinth, Sicyon and Megara. Ptolemy lost Cyprus when Demetrius Poliorcetes defeated Menelaus the brother of Ptolemy 1 Soter at the battle of Salamis. When Antigonus again attempted to invade Egypt in $306 \mathrm{BC}$, Ptolemy resisted him and as a coalition was renewed against Antigonus in 302, Ptolemy joined it and invaded Syria a third time. When he heard that Antigonus had a decisive victory in Asia Minor, Ptolemy left Syria but when again he heard news of Antogonus' defeat and death in the hands of Lysimachus and Seleucus at the Battle of Ipsus in 301, he occupied Syria a fourth time. It is pertinent to note that as the war raged among the Generals of Alexander the Great, cities were won, lost and won again by these men even as opportunities presented themselves. Hence even as

\footnotetext{
${ }^{11}$ Anson, Edward M., 1986, "Diodorus and the Date of Triparadeisus," The American Journal of Philology, 107 (2): 208-217. The Johns Hopkins University Press.
} 
Ptolemy lost many cities in Asia Minor and Greece, he re-conquered Cyprus in about 395/294. He also subdued Cyrene in about 300 BC after series of rebellion and left it in the hands of Magas his stepson. The idea was indeed to consolidate his control over Egypt and her environs as this may aid in keeping enemies at bay.

Having consolidated his control over Egypt and outlying zones, he made his son Ptolemy II Philadelphus by Berenice coregent in 289 BC. Ptolemy 1 Soter died in 283 at the age of 84 . He left a well governed, compact and well ordered city to his son. This was a demonstration of his resoluteness to secure his power over Egypt and her environs. Phillips ${ }^{12}$ asserts that his bonhomie and liberal treatment towards his soldiers of Macedonian and Greek extraction as well as conciliation of the natives, prompted his various successes in the wars. He was also a ready patron of letters even as he established the Library of Alexandria. Adding to the achievements of Ptolemy 1 Soter was the fact that he sponsored the mathematician Euclid in his work titled the The Elements Books IXIII ${ }^{13} \mathrm{He}$ also wrote a history of the campaigns of Alexander the Great. Although the work is not extant however, it was considered an objective treatise. This is so much so that Arrian of Nicomedia, the author of the account of Alexander the Great, stated that he relied heavily on Ptolemy's treatise because as king, it would have been too dishonourable to resort to mendacity. ${ }^{14}$ It is highly plausible though that even as he wrote that history, Ptolemy may have also exaggerated his roles as a General under the leadership of Alexander the Great and as the leader or satrap of Egypt and her environs. ${ }^{15}$

\footnotetext{
${ }^{12}$ Phillips, Heather A., 2010, "The Great Library of Alexandria” Library Philosophy and Practise.

${ }^{13}$ Euclid, 2006, The Elements: Books 1-XII, translated by Thomas L Heath, Barnes \& Noble; Robinson, Victor, 2005, The Story of Medicine, p. 80, Kessinger Publishing.

${ }^{14}$ Henige, David, 2005, Historical Evidence and Argument, p. 108, University of Wisconsin Press.

${ }^{15}$ Bosworth, A.B. 1976, "Errors in Arrian," The Classical Quarterly, New Series, Vol. 26, No. 1, pp. 117-139.
} 
That may not be as important as Ptolemy's achievements in securing, restructuring Egypt and her outlying areas against incursions, and placing Egypt on a pedestal of good success. His entire successors should have adopted the principle of establishing defined procedures already laid down by Ptolemy 1 Soter and become more strategic in their activities as leaders of their cities.

\section{Ptolemy II Philadelphus}

He succeeded his father Ptolemy 1 Soter in 283 BC. During his reign, Egypt entered into several wars. Megas of Cyrene warred against Egypt in 247, Antiochus 1 Soter the Seleucid king also warred against Philadelphus because of Coele-Syria and Judea. Philadelphus also adopted his father's strategies during his reign. He displayed power politics which enabled him to consolidate his control over Egypt and her environs. He also knew when to broker peace. Consequently, after about three years, Egypt became the undisputed naval power of the Eastern Mediterranean. His influence also extended to Cyclades, Samothrace, Cilicia Trachea, Pamphylia, Licia and Caria. He outwitted Gaulic mercenaries he had hired in $270 \mathrm{BC}$ and who eventually turned against him when they plotted to take control of Egypt. Hinds ${ }^{16}$ (2009), states that he abandoned them on a deserted island in the River Nile. They perished as a result of famine. Although Antigonus II Gonatas, the Macedonian king defeated the Egyptian fleet at Cos between 258 and 256 BC, Ptolemy's command of the Aegean Sea continued later. In the second Syrian war, Ptolemy lost on the seaboard and had to sign a peace treaty with the Seleucid king Antiochus II Theos in which Antiochus married Ptolemy's daughter Berenice in $250 \mathrm{BC}$.

It is pertinent to state that Ptolemy did improve on the works of his predecessor, even as he took the material and literary splendour of the Alexandria court to the greatest height. He encouraged the display of exotic animals from far away lands. In honour of Dionysius, Ptolemy also had a procession that was led by 24 chariots drawn by elephants and other animals such as, leopards,

\footnotetext{
${ }^{16}$ Hinds, Kathryn, 2009, Ancient Celts, p. 38. Marshall Cavendish.
} 
lions, antelopes, wild asses, ostriches, a bear, panthers, camels, a giraffe and a rhinoceros. ${ }^{17}$ Ptolemy also adopted concepts from the religion of the Egyptians which portrayed him in positive light with the natives. He increased the library and patronized scientific research. He was truly distinguished that Callimachus the keeper of the library, Theocritus ${ }^{18}$ and several poets praised the Ptolemaic family. He also had relations with India possibly for the purpose of adopting some of her religious concepts. ${ }^{19} \mathrm{He}$ was married to Arsinoe I, daughter of Lysimachus, and the mother of his legitimate children. He later repudiated her and then married his sister Arsinoe II, the widow of Lysimachus. Ptolemy II Philadelphus died in 246 BC and was succeeded by his son Ptolemy III Euergetes. Ptolemy II Philadelphusentered treaties when he knew he lacked the capacity to defeat the enemy. What readily comes to mind is Oliver Goldsmith's ${ }^{20}$ quote, "For he who fights and runs away may live to fight another day; but he who is in battle slain can never rise and fight again." However, he failed to exercise his military might against neighbors he believed he could conquer.

\section{Ptolemy III Euergetes}

During his reign (246 to 222 BC.) he implemented some policies that elevated Egypt to a greater height of power. He built the temple of Horus and the Serapeumin 237 BC. He also built the temple of Karnak. Ptolemy III invaded Syria ${ }^{21}$ because his eldest sister BerenicePhernophorus and her son were killed in a brawl at

\footnotetext{
${ }^{17}$ Scullard, H.H, 1974, The Elephant in the Greek and Roman World, p.125. Thames and Hudson.

${ }^{18}$ Theocritus: Encomium of Ptolemy Philadelphus

${ }^{19}$ Pliny the Elder, Natural History, Chapter 21.

${ }^{20}$ Oliver Golsmith, 1761, The Art of Poetry on a New Plan (1761), vol. ii.

p. 147. Retrieved on 12/11/2015 from http://izquotes.com/quote/232433

${ }^{21}$ Bevan, Edwyn Robert, 1927, A History of Egypt Under the Ptolemaic Dynasty. Methuen;Clayton, Peter A., 2006.Chronicles of the Pharaohs: the reign-by-reign record of the rulers and dynasties of ancient Egypt.Thames \& Hudson.
} 
the Seleucid court. Ptolemy then overran Antioch and even Babylon. He also received some territories on the northern coast of Syria. As he waged war against Antioch, Babylon and Syria, he regained Egypt's stolen art at the time of her conquest by the Persians. He subdued Macedonia and supported the Achaean League. Among his achievements include: work on the Alexandria library and updated the Library with several books; he was tolerant of Egyptian religion; he promoted cults such as those of Apis and Minevis. He died in $221 \mathrm{BC}$ and was succeeded by his son Ptolemy IV Philopator.

The first three Ptolemies were evidently insistent on a greater Egypt, hence the various battles to preserve, promote and protect Egypt and her boundaries. Succeeding Ptolemies became obsessed with power that they failed to take responsibility for Egypt and her people. Therefore, a gradual deterioration of political power and influence became inevitable. Ptolemy Philopator displayed the same power politics his father and grandfather adopted. This placed him on a successful platform in Egypt and over some of her neighbours.

\section{Ptolemy IV Philopator}

His 17 year reign (221 BC to $204 \mathrm{BC}$ ) was marked with trade, ${ }^{22}$ many illegalities and the beginning of the decline of the Ptolemaic dynasty. He was probably weighed down by an inferiority complex which may have made him irresponsible and weak. He inaugurated his reign with the murder of his mother, ${ }^{23}$ and was also hugely influenced by people who were his favourites. Even though he was Pharaoh, he was controlled by his mistress Agathoclea who it was rumoured had a child for him in $219 \mathrm{BC}$, but the child died shortly after birth. These favourites who were sycophants, deceitful and selfish continually indulged him. Consequently, he ran the

\footnotetext{
${ }^{22}$ Hildegard Temporini (ed.) (1978). Politische Geschichte: (Provinzien und Randvölker: Mesopotamien, Armenien, Iran, Südarabien, Rom und der FerneOsten)], Part 2, Volume 9. Walter de Gruyter. p. 977

${ }^{23}$ Polybius, The Histories XV 25.2.
} 
government poorly. The attacks on Antiochus III the Great, his victories over Coele-Syria, Judea and Rapha in 217 BC leading to Ptolemy securing the Northern borders of his kingdom were done by his ministers. However, consolidating the victory was not on his todo-list.

He was a devotee of orgiastic forms of religion and literary dilettantism. He constructed a temple in honour of Homer. He built a massive ship called Tessarakonteres. Plutarch ${ }^{24}$ informs us that Ptolemy owned this vessel. He died in 204 BC and was succeeded by his son Ptolemy V Epiphanes. After his death, there was infighting for the throne. The lure for power caused Agathocles and Sosibus to kill Arsinoe wife of Ptolemy even before she became aware of her husband's death.They thought she had vested interest on the throne. They and their several supporters were also assassinated by the Alexandria mob at the instance of Ptolemy $\mathrm{V}$ Epiphanes having been prompted by Tlepolemus. ${ }^{25}$ Ptolemy IV Philopator's irresponsible and reckless behaviour caused infighting and assassinations. The project of securing Egypt's borders and expanding her territory was not paramount even in the schedule and priority list of Ptolemy IV Philopator and so these assassinations became inevitable making Egypt vulnerable.

\section{Ptolemy V Epiphanes}

A passionate sportsman, who excelled in athletics, took over power in 204BC when he was only five years old. In his 23year reign, he was more or less controlled by several regents and this further led to the decline of Egypt. Under Epiphanes, Phillip V of Macedon took Caria and Thrace which were formerly under Egypt. The Battle of Panium in 198 BC witnessed the transfer of CoeleSyria and Judea from the power of the Ptolemies to that of the Seleucids under Antiochus III the Great. In 193/194 BC, the peace treaty that was concluded between Egypt and the Seleucids saw Antiochus giving his daughter Cleopatra I to Epiphanes in marriage.

\footnotetext{
${ }^{24}$ Plutarch, Demetrius 43.4-5.

${ }^{25}$ Bevan, Chapter 8.
} 
However, Egypt was able to wrest herself of Antiochus' power when war broke out between the later and Rome. He displayed cruelty against rebels while attempting to quell rebellion carried out by the natives. He demonstrated this when he cruelly put to death rebels in Lower Egypt who had earlier surrendered in 183/184 BC on Epiphanes' terms which he had earlier promised to honour. He died in $181 \mathrm{BC}$ and was succeeded by his son Ptolemy VI Philometor.

As seen here, the virtues of an excellent, skilled and strategic leader were obviously not evident in the life of this Pharaoh. From the above narrative, Ptolemy V Epiphanes merely ruled for survival. He was very unlike the founding fathers who built a strong foundation for the Ptolemaic dynasty during their own era.

\section{Ptolemy VI Philometor}

Born in $185 \mathrm{BC}$, he ruled from 181/180 BC with his mother Cleopatra I. After her death, he ruled with his sister Cleopatra II and she bore him four children; Ptolemy Eupator, Ptolemy Neos, Cleopatra Thea and Cleopatra III. In 170 BC, Egypt was invaded twiceby Antiochus IV the Seleucid king who was then crowned as king of Egypt but had to discard it on the orders of the Roman Senate. ${ }^{26}$ Between 169 and 164 BC, Egypt came under the authority of a triumvirate which included Ptolemy, his sister-queen and his younger brother Ptolemy VIII Physcon. As a result of power tussle he was dethroned by his brother, but was restored by Rome when he sought her support. However, he ruled uneasily, cruelly and suppressed rebellions that seemed to have become the order of the day. In $152 \mathrm{BC}$, he ruled jointly with his son Ptolemy Eupator who died later in the year. In $150 \mathrm{BC}$ he gave his daughter Cleopatra Thea's hand in marriage to Alexandar Balas, the Seleucid king.

In $145 \mathrm{BC}$, he invaded Syria and captured Seleucia. This was possible because of the assistance of Jonathan Maccabee, a vassal of Alexander. He also achieved some other feats. He made friends with Demetrius II even as he gave him his daughter in

${ }^{26}$ Livy, AbUrbe Condita, XLV.12 
marriage and crowned himself king of Asia at Antioch. Ptolemy VI Philometordefeated Alexander Balas who fled to Arabia where he was killed. A few days later Ptolemy VI Philometor died in circumstances that were unknown. It was rumoured that he was assassinated by a rival. With this leader, personal interest towered above national interest. Allowing Rome to arbitrate in the affairs of Egypt showed that Egypt was not on a strong footing even before Rome, as Rome, on a later date, annexed Egypt.

\section{Cleopatra II and Ptolemy VII NeosPhilopator}

The identity of Ptolemy VII NeosPhilopator is unclear. It is believed that he was the son of Ptolemy VI Philometor and Cleopatra II. He is said to have begun to co-rule with his father in 145 BC but his uncle Ptolemy VIII Physcon assassinated him (Ptolemy VII NeosPhilopator) and thereafter succeeded him. Ptolemy VII NeosPhilopator co-ruled with his mother Cleopatra II briefly after the death of his father before he was murdered in 145 BC. After him, Cleopatra II and Ptolemy VIII Physcon began to reign.

\section{Cleopatra II and Ptolemy VIII Physcon}

These two kings were two different personalities who exhibited strength during their reign as pharaohs. Under these leaders and between the year 175 and $116 \mathrm{BC}$, assassination politics took the front seat in the political affairs of the Ptolemaic rulers. Assassination was an easy and quick means of doing away with a rival who was perceived as a hindrance to the throne. Sons murdered their mothers, fathers murdered their sons, uncles murdered nephews, siblings murdered each other; all for power. One did not need soothsayers to foretell Egypt's weakness, her vulnerability and her eventual fall in the nearest possible future resulting from this power tussle that caused the death of potentially effective leaders of Egypt.

Cleopatra the daughter of Ptolemy V Epiphanes born in 185 $\mathrm{BC}$, had a history of being regent on several occasions. The first time she reigned as pharaoh, she co-ruled with her brothers Ptolemy 
VI, and Ptolemy VIII ${ }^{27}$ between 175 and 164 BC.She continued with her reign and this second time, between 163 and 127 BC she coruled with her brother-husband Ptolemy VI, her son Ptolemy VII, her brother Ptolemy VIII, andher daughter/sister-in-law Cleopatra III. And again between 124 and 116 BC was Pharaoh alongside Ptolemy VIII and Cleopatra III.

Her marriage to Ptolemy VI Philometor produced four children namely, Ptolemy Eupator, Ptolemy Neos, Cleopatra Thea and Cleopatra III. ${ }^{28}$ Cleopatra Thea was murdered by her son in about 120 BC. Cleopatra III married her uncle Ptolemy VIII who murdered their son.Cleopatra II also married her brother Ptolemy VIII Euergetes II Physcon and they had one son Ptolemy Memphites $^{29}$ who was born between 144 and 142 BC. But he was assassinated by his father in $130 \mathrm{BC}$. Her rule began in $130 \mathrm{BC}$ until $127 \mathrm{BC}$ when she had to abscond to Syria to stay with her son-inlaw Demetrius II Nicator and her daughter Cleopatra Thea.

In $131 \mathrm{BC}$, a rebellion led by Cleopatra ousted Ptolemy VIII, and drove him out of Egypt. Thereafter, Cleopatra enthroned Memphitis who was twelve years old at the time, as Pharaoh. However, Ptolemy VIII Physcon dismembered his son and had his head, hands and feet sent to Cleopatra II in Alexandria as a birthday present. In 124 BC, it was believed that Cleopatra and Ptolemy VIII reconciled albeit publicly. She continued to rule jointly with her brother and daughter. In 116 BC, PtolemyVIII Physcon died and she followed shortly after in the same year. ${ }^{30}$ She was succeeded by Ptolemy the IX and Cleopatra III.

Starting from 169 when hebegan to reign as Pharaoh and until 116 when he died, Ptolemy VIII Physcon had ruled with other Ptolemies. From 169 to 164 BC, he co-ruled with his cognates,

\footnotetext{
${ }^{27}$ Aidan Dodson, Dyan Hilton, 2004, The Complete Royal Families of Ancient Egypt.

${ }^{28}$ Ibid

${ }^{29}$ ibid

${ }^{30}$ Aidan Dodson, Dyan Hilton, 2004, The Complete Royal Families of Ancient Egypt, Thames \& Hudson.
} 
Ptoleny VI and Cleopatra II. Between 144 to $26^{\text {th }}$ June 116 when he died, he reigned with his sister/wife Cleopatra II and his niece/wife Cleopatra III. His reign as pharaoh was punctuated with series of events that fully made Rome a continuous arbiter in the affairs of Egypt.

In $170 \mathrm{BC}$, Ptolemy VI Philometor became a puppet king when he and all of Egypt were captured by Antiochus IV Epiphanes of the Seleucid Empire. While this continued, Ptolemy Euergetes also known as Physcon was chosen as king by the people of Alexandria. Both brothers decided to rule Egypt jointly even as puppet kings. But as Rome threatened, Antiochus withdrew from Egypt in 168 BC. At this period Physcon then agreed to the rule of a triumvirate consisting of Philometor, Cleopatra II (Philometor's wife and their sister) and himself. But the intrigues this caused continued until $164 \mathrm{BC}$ when Philometor visited the Roman senate with regard to the arrangement and areas of their rule. In May $163 \mathrm{BC}$, the original partition was altered and an agreement between the brothers allowed Physcon to be in charge of Cyrenaica. In 161 BC, Physcon attempted to claim Cyprus but failed. In 156/155 BC, Philometor then attempted to assassinate Physcon but failed and as a result, Rome supported his plans to take over Cyprus and offered him resources. This second attempt also failed and Physcon was taken captive by Philometor, but Philometor spared him and gave his daughter Cleopatra Thea as wife to Physcon.

Although Philometor died in $145 \mathrm{BC}$, the power tussle continued. When Physcon returned from battle, he proposed marriage and joint rule to Cleopatra II and she accepted. Physcon then assassinated Ptolemy VII during the wedding feast and claiming the throne, he announced himself as Pharaoh in 144 BC and then displayed his vindictive nature to the detriment of the city. He sent away from Alexandria many people who opposed him including intellectuals: such as philologists, philosophers, professors of geometry, musicians, painters, schoolteachers, physicians, etc. 
Philosophers such as Aristarchus of Samothrace and Appolodorus of Athens were not spared from his wrath. ${ }^{31}$

He also married his wife's daughter, Cleopatra III. Cleopatra II was very infuriated with this development. The Alexandrians were very dissatisfied with his rule and consequently rioted and set the palace ablaze. Physcon, Cleopatra III and their children escaped to Cyprus, but Cleopatra II declared their twelve year old Memphitis Pharaoh. Physcon plotted and killed the boy king and sent his dismembered body to Cleopatra II. Cleopatra II and the city of Alexandria warred against Physcon and the rest of Egypt. Cleopatra desperately sought the aid of the Seleucid king against Physcon and offered him the throne of Egypt. However, his forces failed to penetrate Egypt and so in $127 \mathrm{BC}$, Cleopatra II escaped to Syria. But in $124 \mathrm{BC}$, she returned to Egypt with a formal amnesty decree in $118 \mathrm{BC}$ which of course did not augur well for the government of Physcon and the people of Egypt. When Physcon died in $116 \mathrm{BC}$, he left the throne to Cleopatra III and any one of her sons. She preferred her younger son but the people demanded for her older son, Philometer Soter who at the time was the governor of Cyprus. She complied and Philometer Soter then took the name Ptolemy IX and began to rule. ${ }^{32}$

\section{Ptolemy IX Soter II (Lathyros) and Cleopatra III ${ }^{33}$}

After the death of Physcon, Cleopatra the II ruled briefly before her death in 161 BC with Cleopatra III and Ptolemy IX Soter II nicknamed Lathyros. As co-regent with Physcon she bore him two sons and three daughters namely, Ptolemy IX Tryphaena, Ptolemy X

\footnotetext{
${ }^{31}$ Christian Habicht, Hellenistic Athens and her Philosophers, David Magie Lecture, Citing FGrHist; 270; F 9 Princeton University Program in the History, Archaeology, and Religions of the Ancient World, 1988, p. 9. ${ }^{32}$ Green Peter, 1990, Alexander to Actium, University of California Pre ss. ${ }^{33}$ Information on these pharaohs was retrieved from 1995-2015 Bible Online http://www.biblehistory.com/links.php?cat=46\&sub=3526\&cat_name=People++Ancient+Egypt\&subcat_name=Cleopatra+Berenice+
} 
Alexander I, Cleopatra IV, and Cleopatra Selene I. ${ }^{34}$ But she dotted on the second son, and desired to acclaim him Pharaoh. The people of Alexandria's choice, her first son, Ptolemy IX Soter II Lathyros, prevailed. He was recalled from Cyprus where he ruled as governor and became co-regent with his mother and Ptolemy X Alexander I was sent to Cyprus to replace his brother. Lathytros married his sister Cleopatra IV but Cleopatra II repudiated the marriage replacing Cleopatra IV with her sister Cleopatra Selene. Selene in anger ran away to Cyprus, raised an army and attempted to marry Ptolemy Alexander.

When she failed, she went to Syria and married Antiochus IX Cyzicenus son of Antiochus Sidetes and Cleopatra Thea. Eventually her hatred for Lathyros did not wane for she decided to and chased Lathyros away from Egypt in 107 BC claiming that the latter attempted to assassinate her. Lathyros left behind his two sons and his wife. Alexander I ascended the throne of Egypt, and after six years of rule, murdered his mother Cleopatra III in 101 BC.However, Alexander died in a naval battle and Lathyros returned to Egypt to assume the throne. And as he reigned he carried out actions that angered the people and he was killed; he replaced the sarcophagus of Alexander the Great with one made of glass having melted the original one with the intention of extracting gold for coins. He died at age 62 in $81 \mathrm{BC}$ with no heir to take over the throne for it seemed that his sons and wife had died earlier. His daughter Cleopatra Berenice assumed the throne briefly after his passing.

\section{Berenice III}

She merely ruled for six months, and the people loved her. She was compelled to marry her younger step-son, Ptolemy XI Alexander II in $80 \mathrm{BC}$. Sulla wanted a pro Roman ruler on the throne and so he displayed Ptolemy X Alexander's will that supported the idea of a pro Roman ruler in Egypt. The will also required that Ptolemy

\footnotetext{
${ }^{34}$ Aidan Dodson, Dyan Hilton, The Complete Royal Families of Ancient Egypt, 2004
} 
married Cleopatra Berenice. Buthe murdered and succeeded her and as a result, he was killed by the people ${ }^{35}$

\section{Ptolemy XI Alexander II}

He did not last long on the throne. He willed Egypt to Rome. He was succeeded by his cousin Ptolemy XII. ${ }^{36}$

\section{Ptolemy XII}

Some sources differ on the parentage of Ptolemy XII. He was assumed to have been an illegitimate son of Ptolemy IX Soter by an Egyptian woman. ${ }^{37}$ But another source mentions that he was the son of Ptolemy IX by Cleopatra IV. ${ }^{38}$ His wife, who was either his sister or cousin by the name Cleopatra Tryphaena, is identified as Cleopatra $\mathrm{V}^{39}$ or Cleopatra VI. ${ }^{40}$ His children include; Berenice IV, Cleopatra VII, Arsinoe IV, Ptolemy XIII and Ptolemy XIV. However, the identity of the mother of his three youngest children is unclear. $^{41}$ This aspect of this study has to rely heavily on the

\footnotetext{
${ }^{35}$ http://www.bible-

history.com/links.php?cat $=46 \&$ sub $=3526 \&$ cat_name $=$ People+-
} + Ancient+Egypt\&subcat name=Cleopatra+Berenice+, Ernle Bradford, 2000, Classic Biography: Cleopatra, p 33, Toronto: The Penguin Group. ${ }^{36}$ Peter Green, 1990, Alexander to Actium, p 553-554, University of California Press.

${ }^{37}$ Dodson, Aidan and Hilton, Dyan.The Complete Royal Families of Ancient Egypt.Thames \& Hudson. 2004; Ernle Bradford, Classic Biography: Cleopatra (Toronto: The Penguin Groups, 2000), p. 28. ${ }^{38}$ Ptolemy XII, Chris Bennett ${ }^{39}$ Tyldesley, Joyce, 2006, Chronicle of the Queens of Egypt. Thames \& Hudson.

${ }^{40}$ Dodson, Aidan and Hilton, Dyan, 2004, The Complete Royal Families of Ancient Egypt.Thames \& Hudson.

${ }^{41}$ Dodson, Aidan and Hilton, Dyan, 2004, The Complete Royal Families of Ancient Egypt.Thames \& Hudson. 
Classical authors, Strabo ${ }^{42}$ and Dio Cassius, ${ }^{43}$ since they provide a clearer picture of the person of Ptolemy XII. He was often viewed as a weak king, who was self-indulgent, a drunkard and a lover of music for he loved to play the flute. ${ }^{44}$ Again, he was seen as a reckless person; participating in the contests that he organized at the palace while vying with opposing contestants. Apart from ruling recklessly, he also seemed to thwart the independence and freedom of Egypt when he displayed pro-Roman policy in Egypt. He sent gifts and riches to Pompey who at this time (62BC) had become a prominent fixture on the Roman polity. By the time Julius Caesar became the leader of the Roman State, Ptolemy XII bribed him to the tune of six thousand talents. This resulted in an alliance with the Romans and his name was included in the list amici etsociipopuli Romani, (friends and allies of the Romans). ${ }^{45}$

Because Ptolemy XII refused to speak on the conquest of Cyprus by the Romans, the Egyptians punctuated his reign with a rebellion and consequently he went into exile from 58-55 BC. He was able to get himself restored on the throne of Egypt through lobbying and when the Roman senators realized that they would only get returns on their loans if he was restored, gave full support. In the meantime, Berenice his daughter, succeeded him in $58 \mathrm{BC}$ ruling with her sister or mother, Cleopatra Tryphaena. However, Tryphaena died and Berenice became sole regent from $57 \mathrm{BC}$ to 56 $\mathrm{BC}$. He returned from exile in $55 \mathrm{BC}$. When the Egyptian heard about Ptolemy XII's restoration, they protested against this idea but it is believed that Ptolemy poisoned Dion, the leader of the about

\footnotetext{
${ }^{42}$ Strabo 12.3 .34 and 17.1 .11

${ }^{43}$ Cassius Dio, 39.12 - 39.14, 39.55 - 39.58

${ }^{44}$ Ernle Bradford, 2000, Classic Biography: Cleopatra, p. 34. Toronto: The

Penguin Groups.

${ }^{45}$ Siani-Davies, Mary, 1997, "Ptolemy and the Romans" Historia 46:3 p. 316.
} 
100 people who protested and had other members of the group assassinated before they could achieve their goal. ${ }^{46}$

Ptolemy XII was restored after he had paid Aulus Gabinius ten thousand talents to attack Egypt. Gabinius defeated Egypt's frontier forces but did not attack the palace guards because they surrendered. Ptolemy XIIgot his throne back in $55 \mathrm{BC}$ and his first action was the execution of Berenice and her supporters. Cleopatra VII, his daughter ruled jointly with him. He was restored in $55 \mathrm{BC}$ with the support of Rome who, at this period, exerted authority over Egypt. Roman creditors wanted their money back. The money could not be paid. Anyhow, he appointed Gaius Rabirius Postumus, as minister of finance. He was a major creditor and so was placed in charge of repayment of debt. With this new development, Rabirius had access directly to the financial resources such that he depleted Egypt's resource and exploited the land. It was to such an extent that the king decided to imprison Rabirius to save his neck from the disapproving public and then aided his escape. Rabirius arrived Rome where he was accused of de repetundis (extortion) but Cicero defended him. Ptolemy XII also devalued Egyptian coinage such that it became fifty percent less than its initial value. Ptolemy XII cared less about Egypt, her frontiers, her people and even the dignity and respect that goes with the throne. He sacrificed all these on the altar of his ambitions to become Pharaoh. ${ }^{47}$ He took ill in $51 \mathrm{BC}$. But before he passed away, he willed the throne to Cleopatra VII and her brother Ptolemy XIII and he demanded that Rome become the executor of his will. ${ }^{48}$

\footnotetext{
${ }^{46}$ Siani-Davies, Mary, 1997, "Ptolemy and the Romans" Historia 46:3 p. 325.

${ }^{47}$ Ernle Bradford, 2000, Classic Biography: Cleopatra, p. 37. Toronto: The Penguin Groups.

${ }^{48}$ Siani-Davies, Mary, 1997, "Ptolemy and the Romans" Historia 46:3, p. 339.
} 


\section{Ptolemy XIII and Cleopatra VII}

Ptolemy XIII Neos Philopator became Pharaoh of Egypt with Cleopatra VII his sister after his marriage to her in $51 \mathrm{BC}$. However, although he was the evident ruler, the eunuch Pothinus acted on his behalf for Ptolemy XIII was 12 years of age at the time. $\mathrm{He}$, alongside Pothinus attempted to displace Cleopatra in 48BC because she undermined him and was not subservient. Her face was noted on coins and her name on official documents while those of Ptolemy were not. Ptolemy XIII and Ponthinus were able to depose Cleopatra forcing her to escape to Syria. She in retaliation raised an army with the intention of warring with Ptolemy XIII. However, her sister's, Arsinoe IV's claim to the throne complicated and worsened the already degrading situation. During this period of brouhaha, the Roman General, Pompey the Great visited Egypt while fleeing from Julius Caesar. However, on the $29^{\text {th }}$ of September, 48 BC, Ptolemy XIII assassinated Pompey hoping to win Caesar's favour. This action angered Caesar who was not pleased at the death of Pompey, whom Caesar held in high esteem irrespective of the fact that they had become enemies at this time. Cleopatra took the opportunity to seek Caesar's favour and eventually became his lover. Cleopatra ascended the throne of Pharaoh co-ruling with her brother Ptolemy XIII. However, Ptolemy XIII aligned with Arsinoe IV with the intention of bringing Cleopatra VII down. Unfortunately, they lost, but not after they had destroyed some edifices. Plutarch ${ }^{49}$ tells us that they burned some buildings which held the Library of Alexandria. Roman aid resulted in Ptolemy XIII's defeat and later death. Thereafter, Cleopatra became the undisputed ruler of Egypt. One cannot ignore the fact that Cleopatra singlehandedly placed Egypt on a platform of good success. After Caesar's death, she became Mark Anthony's lover and won many towns for Egypt. These towns were gifts from Mark Anthony, the greatest Roman at the time. Moreover, Egypt did not come under Roman domination during Caesar's or Mark Anthony's consulship,

${ }^{49}$ Plutarch, Life of Julius Caesar, 49:3. 
but under the leadership of Octavian, Egypt became a Roman province in $30 / 31 \mathrm{BC}$.

\section{Conclusion}

Apart from the first three Ptolemies that ruled Egypt purposefully, succeeding Ptolemies seemed to have lacked an understanding of what effective leadership entailed. The idea of power politics displayed by a leader should augur well for any nation even in antiquity, as it translates to mean that the leader considers his nation's interest much more than that of the interests of neighbouring kingdoms. The first three Ptolemies placed national interests above their personal interests and above the interest of other nations. A state that practices a defensive rather than the offensive stance had the propensity to be brought down by the nation that operates the offensive as well as defensive strategies. Ptolemies I Soter, Philadelphus and Eugertes practiced the defensive and offensive strategies even as they played power politics. The results were evident; Egypt was prosperous, her frontiers extended and she became a force to be reckoned with in that period.

Succeeding Pharaohs lacked the capacity to rule. Their aspirations to the throne were merely borne out of the desire to obtain power and exercise that power over perceived enemies. Assassinations of potentially effective leaders became the politics of the day. These leaders failed to build an effective army, they failed to rally the nation round, they failed to plan for an Egypt greater than their days and they failed to protect Egypt. What was witnessed was Egypt's gradual degradation caused by the infighting and continuous killings of family members who were potentially effective pharaohs, all for power. This politics of assassination among others weakened and ruined Egypt and made her vulnerable such that Rome became an arbiter in her affairs. Consequently, Rome occupied Egypt and she became a Roman province in 31BC.

*Monica Omoye Aneni PhD, Department Of Classics, University Of Ibadan, Email: monaneni@yahoo.com 


\section{Bibliography}

Aidan Dodson, Dyan Hilton, 2004, The Complete Royal Families of Ancient Egypt, Thames \& Hudson.

Anson, Edward M., 1986, "Diodorus and the Date of Triparadeisus," The American Journal of Philology.The Johns Hopkins University Press.

Arrian, 1976, Annabasis of Alexander, translated by Brunt, P.A. Harvard University Press.

Bard, Kathryn A., ed., 1999, Encyclopedia of the Archaeology of Ancient Egypt. Routledge.

Bevan, Edwyn Robert, 1927, A History of Egypt Under the Ptolemaic Dynasty. Methuen.

Bingen, Jean, Midgley, Stuart, \&Bagnall, Roger, 2007, Hellenistic Egypt, Society, Economy, Culture (Hellenistic Culture and Society).University of California Press.

Bosworth, A.B. 1976, "Errors in Arrian," The Classical Quarterly, New Series, Vol. 26, No. 1.

Cassius Dio, Roman History, retrieved on 20/02/2015 from http://penelope.uchicago.edu/Thayer/E/Roman/Texts/Cassiu s Dio/39*.html

Chauveau, Michel, 2000, Egypt in the Age of Cleopatra: History and Society Under the Ptolemies, Cornell University Press.

Chris Bennett, Ptolemy XII, retrieved 22/02/2015 from http://www.tyndalehouse.com/Egypt/ptolemies/genealogy.ht $\underline{\mathrm{m}}$

Christian Habicht, Hellenistic Athens and her Philosophers, David Magie Lecture, CitingFGrHist; 270; F 9 Princeton University Program in the History, Archaeology, and Religions of the Ancient World, 1988.

Clayton, Peter A., 1994.,Chronicle of the Pharaohs, London, England: Thames and Hudson.

Clayton, Peter A., 2006. Chronicles of the Pharaohs: the reign-byreign record of the rulers and dynasties of ancient Egypt.Thames \& Hudson.

Dodson, Aidan; Hilton, Dyan, 2004, The Complete Royal Families of Ancient Egypt. London, England: Thames \& Hudson 
Ernle Bradford, 2000, Classic Biography: Cleopatra, Toronto: The Penguin Groups.

Euclid, 2005, The Elements: Books 1-XII, translated by Thomas L Heath, Barnes \& Noble

Green Peter, 1990, Alexander to Actium, University of California Press.

Henige, David, 2005, Historical Evidence and Argument, University of Wisconsin Press.

Hildegard Temporini (ed.), 1978,Politische Geschichte: (Provinzien und Randvölker: Mesopotamien, Armenien, Iran, Südarabien, Rom und der FerneOsten)], Part 2, Volume 9. Walter de Gruyter.

Hinds, Kathryn, 2009, Ancient Celts, Marshall Cavendish. http://www.bible-

history.com/links.php?cat $=46 \&$ sub $=3526 \&$ cat_name $=$ Peopl $\underline{\text { e}+-+ \text { Ancient }+ \text { Egypt\&subcat name }=\text { Cleopatra }+ \text { Berenice }+}$

Hobl, Gunther, 2001,A History of the Ptolemaic Empire, Psychology Press

Jones, Prudence J., 2006. Cleopatra: A Sourcebook. University of Oklahoma Press.

LiviusTtius,AbUrbe Condita, The History of Early Rome, translated by Aubrey de Sélincourt,1973.. Penguin Books.

Manning J.G., 2012, The Last Pharaohs: Egypt Under the Ptolemies, 305-30 BC.Princeton University Press.

Phillips, Heather A., 2010, "The Great Library of Alexandria" Library Philosophy and Practise.

Pliny the Elder, Natural History, translated by $\mathrm{H}$ Rackham 1945.Loeb Classical Library.

Plutarch, 1920.The Parallel Life;The Life of Demetrius. Loeb Classical Library, retrieved from http://penelope.uchicago.edu/Thayer/E/Roman/Texts/Plutarc h/Lives/Demetrius*.html

Plutarch, 1999.The Parallel Life; The Life of Julius Caesar, Loeb Classical Library, retrieved from 
http://penelope.uchicago.edu/Thayer/E/Roman/Texts/Plutarc $\mathrm{h} /$ Lives/Caesar*.html

Polybius, The Histories, 1922, Loeb Classical Library, retrieved from http://penelope.uchicago.edu/Thayer/E/Roman/Texts/Polybi us/15*.html.

Pomeroy, Sarah B., 1990, Women in Hellenistic Egypt. Wayne State University Press.

Robinson, Victor, 2005, The Story of Medicine,,Kessinger Publishing.

Scullard, H.H, 1974, The Elephant in the Greek and Roman World. Thames and Hudson.

Siani-Davies, Mary, 1997, "Ptolemy and the Romans" Historia 46:3. Strabo, The Geography of Strabo, 1917, Loeb Classical Library, retrieved from http://penelope.uchicago.edu/Thayer/E/Roman/Texts/Strabo/ $12 \mathrm{~A}^{*} . \mathrm{html}$.

Theocritus, Encomium of Ptolemy Philadelphus, translated by Richard Hunter, 2003, University of California Press.

Tyldesley, Joyce, 2006, Chronicle of the Queens of Egypt. Thames \& Hudson. 